\title{
Characterization of grid-connected photovoltaic systems in Curitiba, Brazil
}

\author{
Fabianna Stumpf Tonin 1*, Jair Urbanetz Junior ${ }^{1,2}$ \\ 1 Programa de Pós-Graduação em Sistemas de Energia, Universidade Tecnológica Federal do Paraná, \\ Curitiba, Paraná, Brasil; 2 Programa de Pós-Graduação em Engenharia Civil, Universidade Tecnológica \\ Federal do Paraná, Curitiba, Paraná, Brasil.
}

\begin{abstract}
In the search for new options for the establishment of the energy matrix of Brazil, the Grid-Connected Photovoltaic Systems (GCPVS) are configured as an alternative to urban centers, because they allow the power generation at distributed mode, that is, generate energy at the place where it will be consumed and inject the surplus energy into the network. Faced with the prospect of installing Grid-Connected Photovoltaic System, the objective of this research is to characterize this type of photovoltaic system installed in Curitiba, State of Paraná, Brazil. This paper highlights that up to July 2017 the State of Paraná has 1031 GCPVS in operation, which corresponds to 6,6MW, while Curitiba has 204 GCPVS that represents $997.4 \mathrm{~kW}$ in operation, $82 \%$ of which are installed in residences. In addition, the study of a sample of 41 GCPVSs installed in Curitiba shows that $98 \%$ of these systems use multicrystalline modules, $75 \%$ use single phase inverters and $95 \%$ of these use inverters transformerless. This shows that the losses in the conversion process are reduced and the equipment is more compact using better technology than the inverters with transformer. Therefore, the main trend of photovoltaic energy market is to use transformerless inverters.
\end{abstract}

Keywords: Grid-Connected Photovoltaic Systems; Distributed Generation; Solar Energy.

\footnotetext{
*Author of correspondence: fstonin@gmail.com
} 


\section{INTRODUCTION}

The progressive increase in the consumption of electric energy and the shortage of water resources implies the search for alternatives to diversify the electric matrix of Brazil and supply the country's energy demand ${ }^{1}$. Currently, renewable energies, such as solar energy, wind and biomass, are considered more sustainable options. Distributed photovoltaic solar generation, which involves the production of energy closer to the consumer's, is a new strategy that may be useful especially in large Brazilian cities ${ }^{2}$, since the energy generated by the sun is inexhaustible, both as heat and light ${ }^{3}$.

Moreover, this type of energy has an huge potential to be exploited in Brazil. The installed and operating capacity of photovoltaic generation in the country is only $238 \mathrm{MWp}$ ( July 2017), according to the National Electric Energy Agency (ANEEL) ${ }^{4,5}$. On the other hand, China, the country with the largest photovoltaic generation, has more than $77.4 \mathrm{GWp}$ installed and in operation, of which $34.54 \mathrm{GWp}$ were added in the year 2016, according to the International Energy Agency (IEA) ${ }^{6,7}$.

However, there is still a lack in the literature of the characterization of the Photovoltaic Systems Connected to the Electrical Network (GCPVS) installed in Brazil. The knowledge of the main characteristics of this system may contribute to the insertion of the photovoltaic generation in the country's electric matrix and support a more sustainable energy planning.

Thus, the present work aims to evaluate the profile of the GCPVS installed in the city of Curitiba, State of Paraná, Brazil.

\section{MATERIAL AND METHODS}

This work is a descriptive study of the photovoltaic systems installed in the city of Curitiba, capital of the State of Paraná, Brazil. Initially, the main characteristics of power range and A or B Groups were pooled from the database of the National Electric Energy Agency - ANEEL (www.aneel.gov.br) to provide a broader overview of energetic scenario.

Then, a sample of 41 systems installed by the two main companies of the State (ELCO - 31 systems and SOLAR ENERGY - 10 systems) were selected for an in-depth analyses. Data made available by the companies on the power range of the inverters used, the mode of installation of the modules and the technology of the photovoltaic cells used were collected.

The variations of the power systems (both added and cumulative) were assessed over the years. Descriptive analyses were conducted with all variables and are reported as absolute and relative frequencies.

\section{RESULTS AND DISCUSSION}

According to data available on micro and mini geration by ANEEL, the State of Paraná has 1031 GCPVS installed and in operation (up to July 2017). These systems have a total value of $6.65 \mathrm{MWp}$, of which $2.98 \mathrm{MWp}$ are installed at residential homes. The year 2016 showed the highest number of connections of the GCPVS with the utility network, comprising 538 connections. It is worth mentioning that in the first seven months of 2017, a total of 366 connections were recorded, which represents $2676.75 \mathrm{kWp}$ installed in the State of Paraná ${ }^{8,9}$. Figure 1 shows the evolution of the installed capacity of GCPVSs in Paraná ${ }^{8}$. 


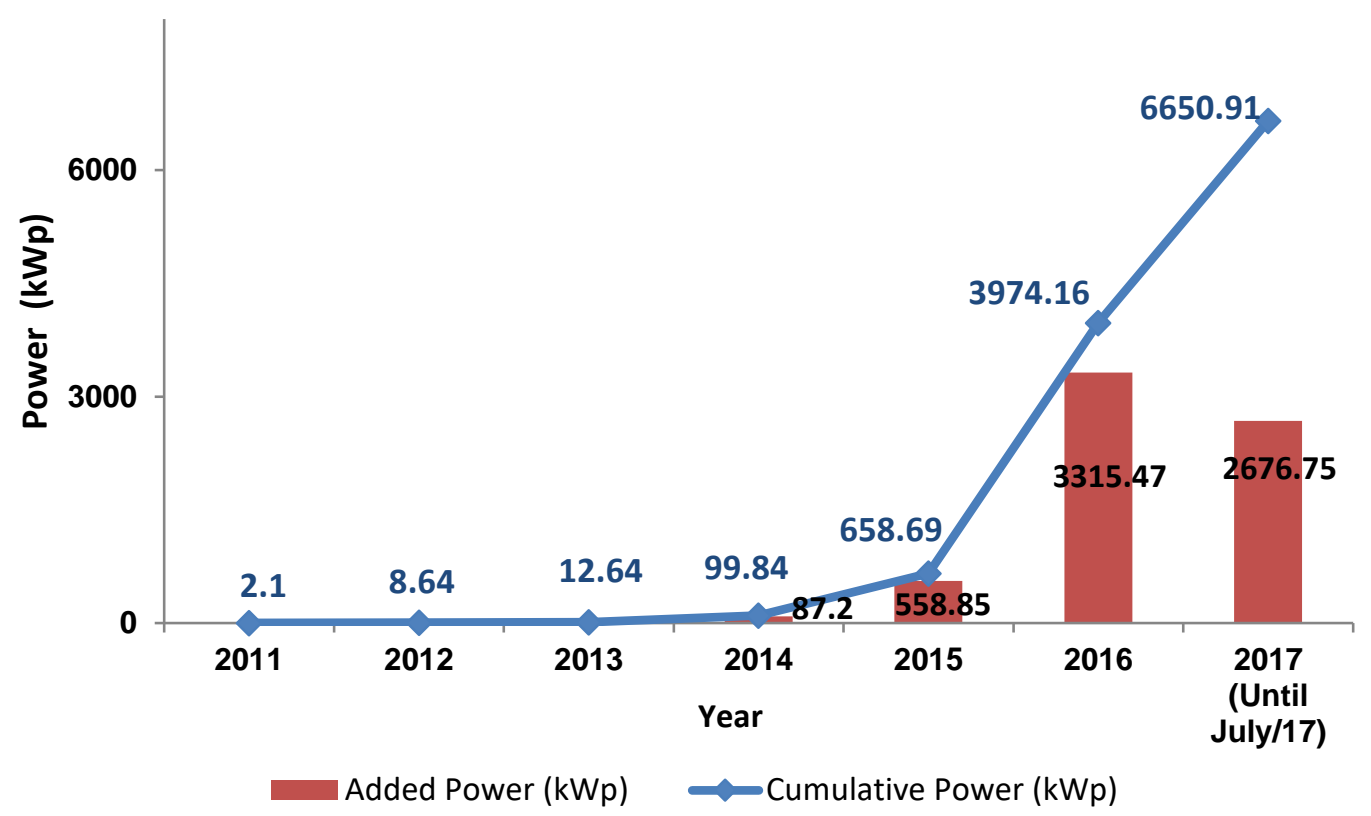

Figure 1 - Installed Power in the State of Paraná

The city of Curitiba has registered, a total of 204 GCPVSs installed and in operation from 2011 to July 2017, thus adding a power of $997.4 \mathrm{kWp}$. The highest number of connections were made in 2016, a total of 101 GCPVSs ${ }^{8,9}$. It is important to highlight that before the publication of ANEEL's resolution n. 482 on the regulation of GCPVSs, Curitiba had already two systems installed. These systems are: (i) the GCPVS $2.1 \mathrm{kWp}$ installed in the Green Office of the Technological Federal University of Paraná (UTFPR) in 2011, and (ii) the GCPVS $8.64 \mathrm{kWp}$ of ELCO company, installed at the company's headquarters at the beginning of 2012. The ELCO's system was the first GCPVS to be homologated by the Energetic Company of Paraná (COPEL) on October 2nd, $2013^{9}$.

For three times from 2015 to 2016, an accumulated increase on the power range could be noticed - from $235.9 \mathrm{kWp}$ to $733.08 \mathrm{kWp}$-. Additionaly, in the first seven months of 2017 there is already a total of $264.32 \mathrm{kWp}$ of installed power, as can be seen in Figure 2. 


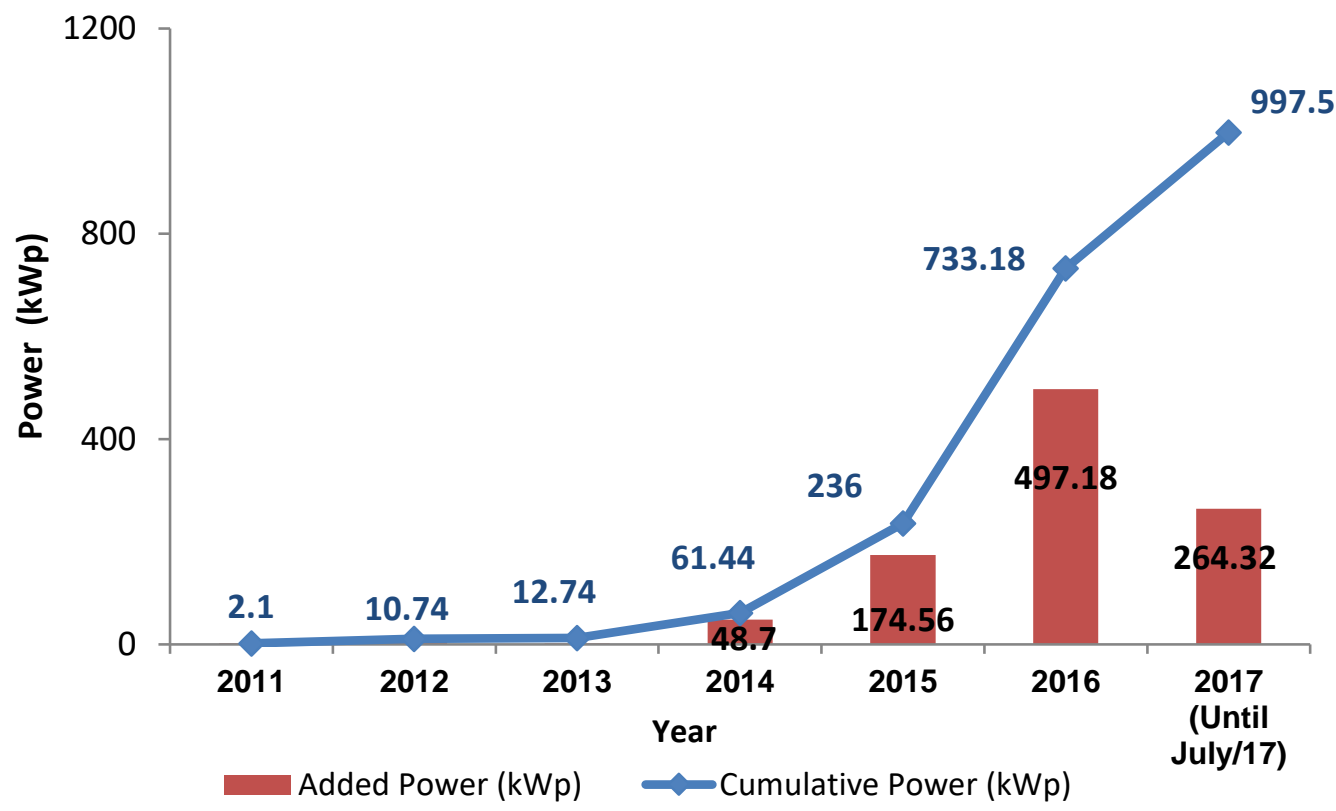

Figure 2 - Installed Power in Curitiba

Considering the consumer units installed in Curitiba, they are subdivided into Group A or B, according to the supply voltage. All units that have a power supply of $2.3 \mathrm{kV}$ or more belong to Group A, whereas Group B is composed of units with voltage supply below $2.3 \mathrm{kV}{ }^{10}$. Figure 3 shows the consumer units groups of the GCPVS installed in Curitiba. Group B accounts for 96\% of the installed systems, corresponding to a power of $809.13 \mathrm{kWp}^{8}$.

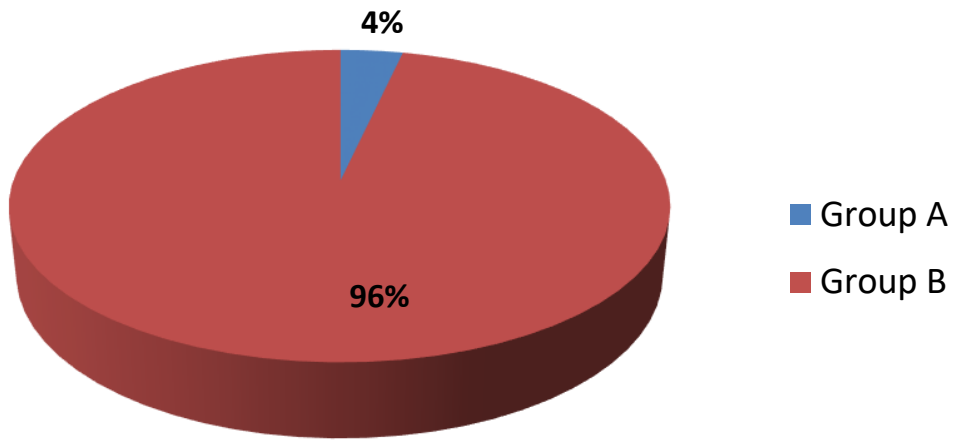

Figure 3 - Subdivision into consumer units (Group A and Group B) installed in Curitiba

This Group B is subdivided into residential, commercial and industrial units, as shown in Figure 4. Residential units correspond to 82\% of the GCPVS installed in Curitiba, with a total capacity of $508.32 \mathrm{kWp}$, while the commercial units represent 29 of the GCPVS with a total power of 242.69 $\mathrm{kWp}^{8}$. 


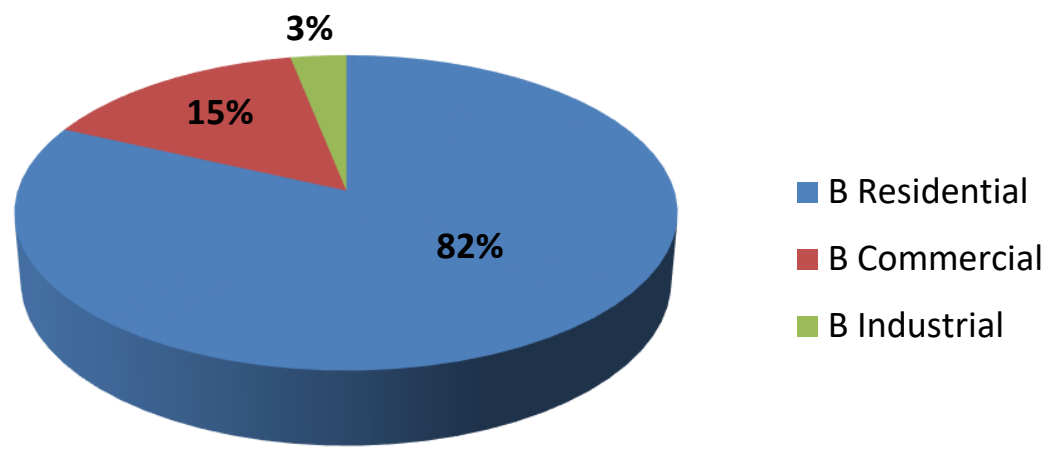

Figure 4 - Subdivision of Group B - Residential, Commercial and Industrial units in Curitiba

According to the power range of the systems, the GCPVSs installed in Curitiba have three main divisions as shown in Figure 5. The systems with powers below $5 \mathrm{kWp}$ are the great majority, with a total of 164 systems, representing $81 \%$ of the systems installed in the capital. Systems with power equal to or greater than $10 \mathrm{kWp}$ are outnumbered, accounting for only $8 \%,(17$ systems).

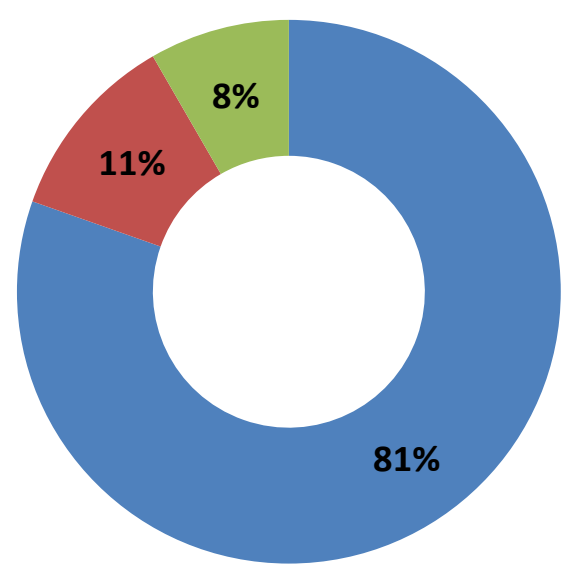

$$
\begin{aligned}
& \text { Less than and/or } \\
& \text { equal to } 5 \mathrm{kWp} \\
& \text { Between } 5 \mathrm{kWp} \text { and } \\
& 10 \mathrm{kWp} \\
& \text { More than and/or } \\
& \text { equal to } 10 \mathrm{kWp}
\end{aligned}
$$

Figure 5 - Power range of the GCPVS installed in Curitiba

Considering our sample of 41 GCPVSs installed in Curitiba by ELCO and SOLAR ENERGY, 31 of them (75\%) have power equal to or less than $5 \mathrm{kWp}$. Other 6 GCPVSs have $10 \mathrm{kWp}$ or more, representing $15 \%$ of the systems and lastly, only 4 systems (10\%) have intermediate powers between 5 and $10 \mathrm{kWp}$ (Figure 6). 


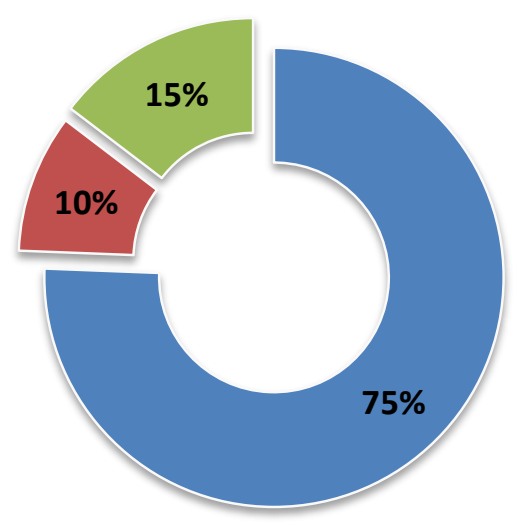

- Less than and/or
equal to $5 \mathrm{kWp}$

- Between $5 \mathrm{kWp}$ and $10 \mathrm{kWp}$

- More than and/or equal to $10 \mathrm{kWp}$

Figure 6 - Power range of the 41 GCPVSs installed in Curitiba

These GCPVSs use mainly inverters without transformers (95\% of the systems) (see Figure 7), because this reduces the energy losses in the inverter and consequently increases the energy efficiency of the system. In addition, transformerless inverters have more advanced technology components and are more compact than transformer inverters ${ }^{11}$. More than half of the systems (21 GCPVS, 51\%) use inverters with a power of $3 \mathrm{~kW}$, while 12 GCPVS (29\%) use inverters with a power of $2 \mathrm{~kW}$, and 6 GCPVSs with a power of $10 \mathrm{~kW}$ $(15 \%)$ (see Figure 8).

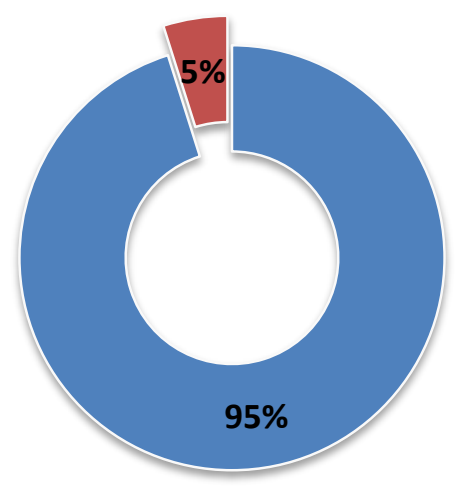

- Transformerless

- With Transformer

Figure 7 - Type of inverters employed in the GCPVSs installed in Curitiba

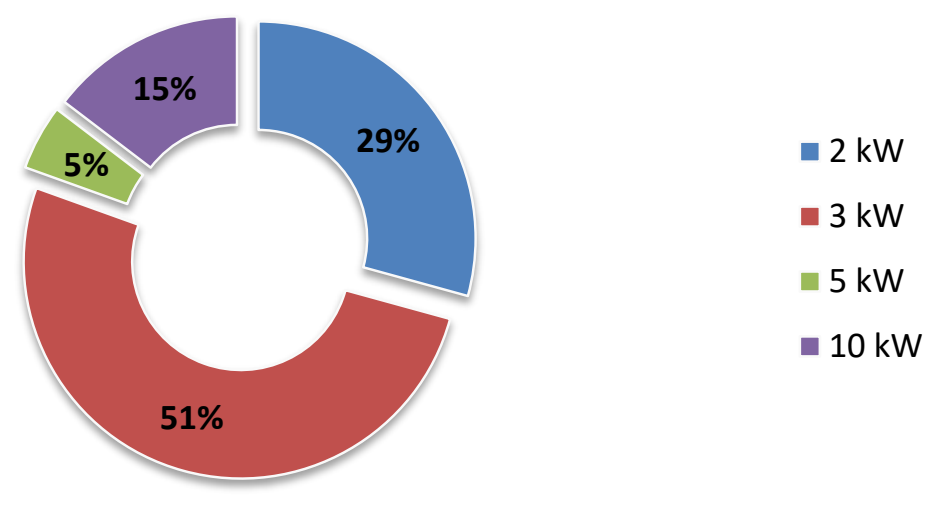

Figure 8 - Inverters power of the GCPVSs installed in Curitiba 
Regarding to photovoltaic cell technology, it was possible to verify that $98 \%$ of these GCPVSs use polycrystalline silicon. The remaining system by ELCO (8.64 $\mathrm{kWp}$ system, the first homologated in the State of Paraná) uses monocrystalline as technology.

All 41 GCPVSs have been installed following the orientation of the roof of the buildings where they are installed and are geographically oriented. Ideally for Curitiba, the systems should be oriented to the geographic north (azimuthal deviation equal to or very close to zero) and with a slope equal to or very close to the value of the latitude of the city, which is 25 degrees. These specificities allow to maximize the incidence of irradiation in the photovoltaic modules and, consequently to increase the generation of electric energy, all year round. Finally, there is a predominance of residential home-installed systems, that proves the feasibility of the distributed solar photovoltaic generation as an excellent alternative to supply the energy demand in the great urban centers of the country. In addition, the evident growth of the photovoltaic generation systems in the electric matrix of Curitiba in the past years highlights the potential use of this strategy.

Our study has some limitations. It was possible to evaluate only a sample of the GCPVSs installed in Curitiba, since no further information about the remaining systems was available. However, we were able to provide an overview of the current energetic scenario and highlight the main strenghts and weaknesses of the systems.

\section{CONCLUSION}

The main contribution of this work is the survey of the profile of the photovoltaic systems connected to the electric grid installed in Paraná. Currently, the State has 1031 GCPVSs in operation which represents a power range of $6.65 \mathrm{MWp}$. The 41 installed GCPVSs in Curitiba are mainly employed in residential units with powers of up to $5 \mathrm{kWp}$, using cells with polycrystalline technology, inverters without transformer and are installed following the geographic orientation of the respective roofs.

Thus, our study confirms the applicability of the distributed photovoltaic generation systems in urban environments. The GCPVSs can effectively provide electric energy near to the points of consumption, requiring no additional area, since they are installed on building's roofs.

\section{REFERENCES}

1- Borges, Helena; Alvarenga, Bianca. As turbinas em risco. Planeta Sustentável, São Paulo, 30 abr. 2014. <http://planetasustentavel.abril.com.br/noticia/energia/asturbinas-em-risco-781672.shtml?func=2>10 ago. 2017

2- EPE. Demanda de Energia. Rio de Janeiro, 2014. http://www.epe.gov.br/Estudos/Documents/DEA\%201314\%20Demanda\%20de \%20Energia\%202050.pdf 08 ago. 2017.

3- Pinho, João Tavares. Galdino, Marco Antonio. Manual de Engenharia para Sistemas Fotovoltaicos. Rio de Janeiro, 2014. 530 p.

4- Agência Nacional de Energia Elétrica. Geração Distribuída. Brasília, 2017. < http://www2.aneel.gov.br/scg/gd/GD_Fonte.asp> 05 ago. 2017.

5- Agência Nacional de Energia Elétrica. Banco de Informações de Geração. Fonte de Energia exploradas no Brasil. 2017. http://www2.aneel.gov.br/aplicacoes/capacidadebrasil/FontesEnergia.asp> 10 ago. 2017.

6- International Energy Agency. China Commentary: The success of wind and solar is powered by strong policy support. 
https://www.iea.org/newsroom/news/2017/june/commentarythe-success-ofwind-and-solar-is-powered-by-strong-policy-support.html. 12 ago. 2017.

7- Digital Trends. China is now the world's largest solar power producer. https://www.digitaltrends.com/cool-tech/china-solar-energy/12 ago 2017.

8- Agência Nacional de Energia Elétrica. Geração Distribuída. Brasília, 2017. < http://www2.aneel.gov.br/scg/gd/gd.asp> 11 ago. 2017.

9- Urbanetz, J.; Chinvelski, T.; Simão, C. A. F.; Makishi, L. M. M. Primeiro sistema fotovoltaico conectado à rede elétrica homologado pela COPEL, V Congresso Brasileiro de Energia Solar - V CBENS, Recife, 2014.

10- Agência Nacional de Energia Elétrica. Resolução Normativa n 414, de 09 de setembro de $2010 . \quad$ Brasília, 2010. http://www.aneel.gov.br/documents/656877/14486448/bren2010414.pdf/3bd332 97-26f9-4ddf-94c3-f01d76d6f14a?version=1.0. 11 ago 2017.

11 - Tonin, Fabianna Stumpf. Caracterização de Sistemas Fotovoltaicos Conectados à Rede Elétrica. Curitiba, 2017. 132p.

Received: December 21, 2017; Accepted: August 01, 2018 